\title{
PERIODE PEMBUNGAAN DAN PEMBUAHAN NYAMPLUNG (Calophyllum inophyllum) PADA TEGAKAN BENIH PROVENAN DI WONOGIRI
}

\author{
Flowering and fruiting period of nyamplung (Calophyllum inophyllum) at provenance seed \\ stand in Wonogiri
}

\author{
Eritrina Windyarini ${ }^{1}$, Tri Maria Hasnah ${ }^{1}$, Hamdan Adma Adinugraha ${ }^{1}$ dan Budi Leksono ${ }^{1}$ \\ ${ }^{1}$ Kontributor Utama, ${ }^{1}$ Balai Besar Penelitian dan Pengembangan Bioteknologi dan Pemuliaan Tanaman Hutan \\ Jl. Palagan Tentara Pelajar KM 15, Purwobinangun, Pakem, Sleman, Yogyakarta, Indonesia \\ email penulis korespondensi : e_windyarini@yahoo.com
}

Tanggal diterima: 07 Desember 2020, Tanggal direvisi: 07 Desember 2020, Disetujui terbit: 24 Desember 2020

\begin{abstract}
Nyamplung (Calophyllum inophyllum) is a potential type of non-timber forest product with high oil yield which is useful as an alternative renewable energy sources and herbal medicine-cosmetics. Result of population selection level in Java island have been used to establish Provenan Seed Stand (PSS) nyamplung in KHDTK Wonogiri (Central Java). Seeds of nyamplung is used as oil raw material which is strongly influenced by flowering and fruiting period. Information on flowering fruiting ability and period is needed to support the availability of raw materials in a sustainable supply for the nyamplung oil industry. Observation of flowering and fruiting period focused on 465 individual trees in nyamplung PSS at KHDTK Wonogiri through monthly monitoring by calculated flowering fruiting individual tree during 5 years (2014-2018). The results showed that the flowering period of nyamplung in (PSS) Wonogiri varied during 2014-2018. Flowering and fruiting occurs almost throughout the year. However, the peak of flowering and fruiting occurs mostly in March-August (end of the rainy season to the middle of dry season). In general, the trend of flowering and fertilization increased in 2014-2016, then decreased in 2017-2018, which is thought to be influenced by the higher canopy density. The environmental factor that most influences flowering is number of rainy days, while fertilization of PSS was strongly influenced by temperature. The management of PSS require future action such: second thinning, top pruning, application of fertilizers and hormones to stimulate flowering, and further detailed observations of flowering fruiting stage and its interaction with microclimate.
\end{abstract}

Keywords: non timber forest product, generative reproduction, microclimate

\begin{abstract}
ABSTRAK
Nyamplung (Calophyllum inophyllum) merupakan jenis Hasil Hutan Bukan Kayu potensial dengan rendemen minyak tinggi yang bermanfaat sebagai alternatif sumber energi baru terbarukan maupun obat dan kosmetik herbal. Hasil seleksi pada tingkat populasi di pulau Jawa telah digunakan untuk membangun Tegakan Benih Provenan (TBP) nyamplung di KHDTK Wonogiri (Jawa Tengah) sebagai sumber benih unggul yang akan menghasilkan nyamplung dengan rendemen minyak dan produktivitas buah yang tinggi. Bagian tanaman nyamplung yang menjadi bahan baku utama minyak adalah biji yang sangat dipengaruhi oleh pembungaan dan pembuahan. Informasi kemampuan dan periode pembungaan dan pembuahan nyamplung sangat diperlukan untuk mendukung ketersediaan bahan baku secara berkelanjutan bagi industri minyak nyamplung. Pengamatan periode pembungaan pembuahan nyamplung difokuskan terhadap 465 individu pohon pada TBP di KHDTK Wonogiri dengan mengamati individu berbunga dan berbuah pada setiap bulan selama 5 tahun (2014-2018). Hasil pengamatan menunjukkan bahwa periode pembungaan pembuahan nyamplung pada 2014-2018 di TBP Wonogiri bervariasi. Pembungaan dan pembuahan hampir terjadi sepanjang tahun. Namun demikian puncak pembungaan dan pembuahan lebih banyak terjadi di bulan Maret- Agustus (akhir musim penghujan hingga pertengahan musim kemarau). Secara umum trend pembungaan pembuahan meningkat pada 2014-2016, kemudian menurun pada 2017-2018 yang diduga dipengaruhi oleh semakin tingginya kerapatan tajuk. Faktor lingkungan yang paling mempengaruhi pembungaan adalah hari hujan, sedangkan pembuahan dipengaruhi kuat oleh suhu. Upaya yang diperlukan dalam pengelolaan TBP di masa datang antara lain : penjarangan kedua, top pruning, pemberian pupuk dan hormon perangsang pembungaan pembuahan, serta pengamatan lanjutan dan detail terhadap proses dan tahapan pembungaan pembuahan dan interaksinya dengan iklim mikro TBP.
\end{abstract}

Kata kunci : hasil hutan bukan kayu, reproduksi generatif, mikroklimat 


\section{PENDAHULUAN}

Tegakan Benih Provenan (TBP) nyamplung di KHDTK Wonogiri merupakan salah satu bagian dari strategi pemuliaan nyamplung untuk penyediaan bahan baku biofuel. TBP dibangun menggunakan materi genetik dari provenan/ras lahan yang mempunyai produktivitas buah dan kualitas biofuel terbaik di Jawa, yaitu Gunungkidul (Leksono \& Widyatmoko, 2010). Nyamplung asal populasi Gunungkidul memiliki rendemen minyak hingga 50\% dengan alat Screw Press Expeller (SPE) (Leksono et al., 2014). TBP nyamplung diharapkan dapat menjadi sumber benih unggul di masa mendatang dengan rendemen minyak dan produktivitas buah yang tinggi. Hingga umur 9 tahun, rendemen minyak dari TBP Nyamplung Wonogiri telah meningkat 14 - 19\% lebih tinggi dibandingkan populasi asalnya di Gunungkidul (Leksono et al., 2015; Leksono et al., 2020).

Bagian tanaman nyamplung yang akan dimanfaatkan sebagai bahan baku biofuel adalah buah yang merupakan hasil penyerbukan antara putik dan benang sari. Dengan demikian kemampuan berbunga dan keberhasilan terjadinya buah/biji (reproductive success) menjadi parameter utama dalam menunjang keberhasilan pelaksanaan strategi pemuliaan nyamplung (Nurtjahjaningsih et al., 2012). Nyamplung di TBP Wonogiri yang berada tepat di sebelah sungai Bengawan Solo (PUP IV dan V) memiliki pertumbuhan tinggi, diameter dan jumlah cabang yang paling baik dibanding PUP nyamplung lainnya. Bahkan kedua PUP tersebut sudah mulai berbuah pada umur 1,5 tahun (pengamatan pribadi). Hal ini menjadi sangat menarik karena sebelumnya disebutkan bahwa nyamplung baru akan mulai berbuah pada umur 7 tahun (Bustomi et al., 2008). Ketersediaan air dan unsur $\mathrm{P}$ dalam tanah menjadi faktor pembatas utama dalam adaptabilitas dan pertumbuhan nyamplung di TBP Wonogiri (Bustomi et al., 2008; Windyarini \& Hasnah, 2014).
Informasi awal terjadinya pembungaan dan pembuahan nyamplung di TBP Wonogiri perlu ditindaklanjuti dengan informasi lanjutan mengenai periode pembungaan dan pembuahan serta kestabilannya, terlebih mengingat umur tanaman yang tergolong muda. Penelitian ini bertujuan untuk mengetahui periode berbunga dan berbuah pada tanaman nyamplung di TBP Wonogiri serta mengevaluasi stabilitas dalam produksi bunga dan buah. Informasi periode pembungaan dan pembuahan sangat dibutuhkan berkaitan dengan periode pengunduhan buah nantinya sebagaimana tujuan awal pembangunan TBP sebagai sumber benih unggul nyamplung.

\section{BAHAN DAN METODE}

Penelitian dilakukan pada plot TBP Nyamplung di KHDTK Wonogiri yang secara administratif berada di Desa Sendang, Kecamatan Wonogiri, Kabupaten Wonogiri, Jawa Tengah. Secara geografis lokasi KHDTK Wonogiri terletak pada $7^{\circ} 32^{\prime} \mathrm{LS}-8^{\circ} 15^{\prime} \mathrm{LS}$ dan $110^{\circ} 4{ }^{\prime} \mathrm{BT}-111^{\circ} 18^{\prime} \mathrm{BT}$. Klasifikasi iklim menurut Schmitdt dan Ferguson termasuk tipe iklim $\mathrm{C}$ dengan curah hujan $1.878 \mathrm{~mm} / \mathrm{tahun}$, hari hujan terbanyak pada bulan Januari, menurun mulai bulan Maret, suhu maksimum berkisar $30^{\circ}-38^{\circ} \mathrm{C}$ dan minimum berkisar $20^{\circ}$ $23^{\circ} \mathrm{C}$, dengan rata-rata kecepatan angin sedang (BBPPBPTH, 2013). Waktu penelitan adalah Januari 2014 - Oktober 2018.

Bahan yang digunakan adalah tanaman nyamplung di TBP tahun tanam 2011. Materi genetik untuk pembangunan TBP berasal dari populasi nyamplung di Gunungkidul. Jumlah tanaman yang diamati sebanyak 465 jarak tanam $5 \times 5 \mathrm{~m}$; ditanam di tepi sungai Bengawan Solo. Sedangkan alat yang digunakan adalah alat tulis dan kamera. Penelitian dilaksanakan secara deskriptif kualitatif. Pengamatan periode pembungaan pembuahan dilakukan dengan cara mencatat dan menghitung prosentase individu yang berbunga dan berbuah setiap bulannya selama 5 tahun (2014-2018). Data sekunder 
faktor lingkungan yaitu jumlah hari hujan, curah hujan, suhu dan kelembaban selama Januari 2014 - Desember 2018 diperoleh dari Badan Pusat Statistik (BPS) Kabupaten Wonogiri. Data dianalisis secara deskriptif menggunakan Microsoft Excel untuk menentukan periode pembungaan dan pembuahan.

\section{HASIL DAN PEMBAHASAN}

Pembungaan dan pembuahan menjadi salah satu indikator kemampuan adaptasi suatu jenis terhadap tempat tumbuhnya (Leksono et al., 2020). Fase pembungaan dan pembuahan pada nyamplung merupakan fase yang menentukan terhadap kuantitas dan kualitas produksi buah/biji yang dihasilkan (Handoko et al., 2013). Bunga nyamplung membutuhkan waktu 27 hari setelah inisiasi untuk berkembang dari tunas hingga menjadi kuncup dewasa dan 10 - 11 minggu setelah anthesis bagi perkembangan buah dari kecil hingga menjadi buah matang (Hamim et al., 2019).

Penelitian ini menunjukkan bahwa nyamplung di TBP Wonogiri yang berada di tepi sungai Bengawan Solo telah mulai belajar berbunga dan berbuah pada umur 1,5 tahun, jauh lebih cepat dibandingkan nyamplung di hutan tanaman Purworejo yang baru mulai berbuah pada umur 6 - 7 tahun (Bustomi et al., 2008; Leksono et al., 2010). Pohon nyamplung muda di Penisular India mulai berbunga setelah berumur 7 - 8 tahun (Prabakaran \& Britto, 2012). Ketersediaan air dan unsur $P$ dalam tanah menjadi faktor pembatas utama dalam adaptabilitas dan pertumbuhan nyamplung di TBP Wonogiri (Bustomi et al., 2008; Windyarini \& Hasnah, 2014). Benih nyamplung dari TBP Wonogiri yang ditanam pada lahan eks kebakaran di Bukit Soeharto (Kalimantan Timur) mulai belajar berbunga dan berbuah pada umur 2 tahun ( Leksono et al., 2020). Sedangkan $C$. soulatri pada lahan gambut terdegradasi di Siak (Riau) mulai belajar berbunga dan berbuah pada umur 3 tahun (Darwo \& Bogidarmanti, 2016). Sementara pada jenis penghasil minyak nabati lain seperti kemiri sunan, bahan tanaman dari hasil grafting akan memulai pembungaan pada umur 3 tahun (Herman et al., 2013). Sedangkan Pongamia pinnata di India mulai berbuah pada umur 5 - 7 tahun setelah tanam (Bala et al., 2011).

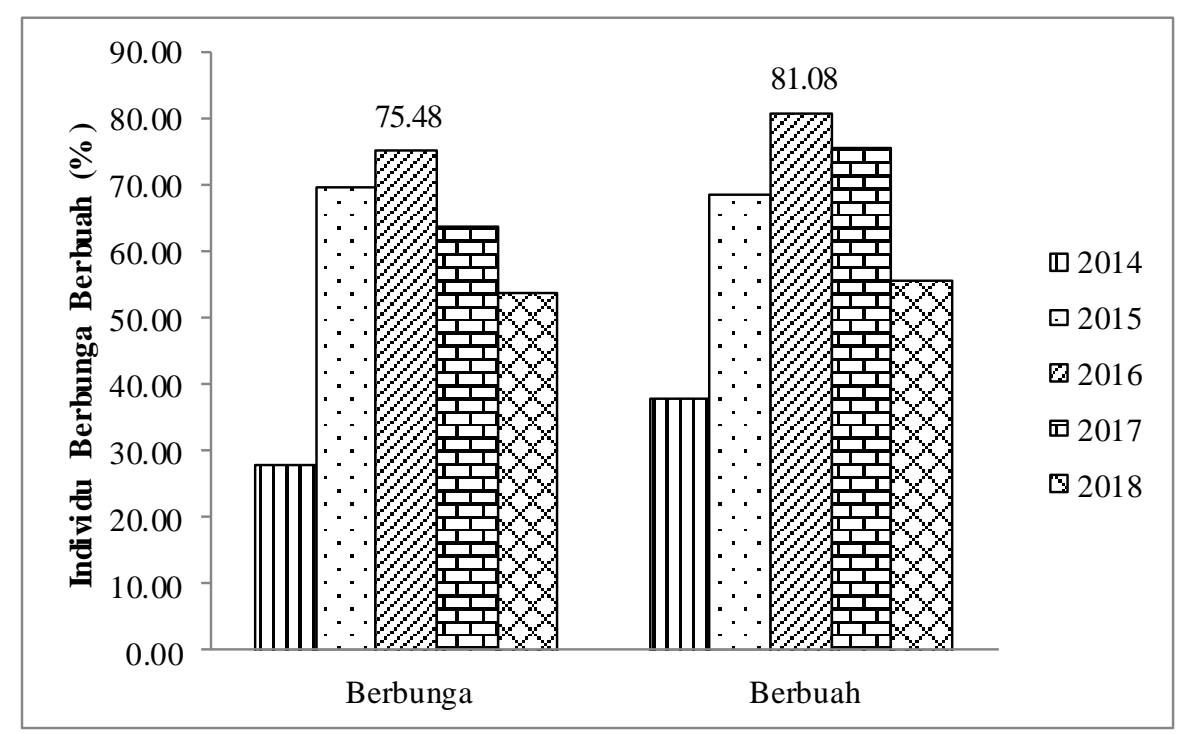

Gambar 1. Individu berbunga dan berbuah pada 2014-2018 TBP nyamplung Wonogiri

Dari hasil pengamatan selama 5 tahun diketahui bahwa nyamplung TBP Wonogiri memiliki persen individu berbunga dan berbuah yang bervariasi. Persentase individu berbunga berbuah terendah di 2014 dan mencapai puncak di 2016. Individu berbunga berkisar 27,96\% 
(2014) hingga 75,48\% (2016), sedangkan kisaran individu berbuah $38,06 \%$ (2014) hingga $81,08 \%$ (2016). Persen individu berbunga berbuah 2014 menjadi yang terendah karena tanaman nyamplung saat itu masih berumur 3 tahun. Pembungaan dan pembuahan pertama di TBP terjadi pada umur 1,5 tahun (Juli 2013), kemudian pada bulan Desember 2013 ditemukan sebanyak 9 individu berbunga $(1,94 \%)$ dan 7 individu berbuah $(1,51 \%)$ (Leksono et al., 2013). Data di atas menunjukkan bahwa pembungaan pada tahun 2014 merupakan fase belajar berbunga dan berbuah. Kemudian pada 2015 persen individu berbunga menjadi $69,68 \%$ (meningkat $149,23 \%$ ) dan berbuah $80,79 \%$ (meningkat $80,79 \%$ ) dibandingkan tahun 2014. Selama pengamatan, persentase individu berbunga dan berbuah terbanyak terjadi pada 2016 (umur 5 tahun) kemudian cenderung menurun di 2017 dan 2018. Faktor-faktor internal yang mempengaruhi antara lain genetik, umur tanaman, status hara, aktivitas kambium dan status hormon (Baskorowati, 2013). Sedangkan faktor-faktor eksternal antara lain lingkungan, naungan, suhu dan distribusi hujan serta kelembaban udara (Anita-sari \& Susilo, 2013). Dari informasi pada Tabel 1, diketahui bahwa pada tahun 2016, Wonogiri mempunyai rerata kondisi iklim bulanan berupa hari hujan, curah hujan dan suhu udara tertinggi berturut-turut sebesar 15 hari; 252,50 $\mathrm{mm}^{3}$ dan $28,6^{\circ} \mathrm{C}$ dibanding waktu pengamatan lainnya (Tabel 1). Dengan demikian tingginya persentase individu berbunga dan berbuah pada 2016 berkorelasi positif dengan tingginya jumlah hari hujan, curah hujan dan suhu udara yang ada di lokasi pengamatan selama tahun 2016.

Tabel 1. Rerata kondisi iklim di Wonogiri 2014-2018

\begin{tabular}{lrrrrr}
\hline \multicolumn{1}{c}{ Rerata kondisi iklim } & & 2015 & 2016 & 2017 & 2018 \\
\hline Hari hujan & 2014 & 6.25 & 15.42 & 7.92 & 8.83 \\
Curah hujan $(\mathrm{mm})$ & 5.75 & 139.67 & 252.50 & 186.25 & 124.00 \\
Suhu udara $\left({ }^{\circ} \mathrm{C}\right)$ & 27.26 & 27.50 & 28.60 & 26.99 & 27.27 \\
Kelembaban $(\%)$ & 90.35 & 84.79 & 87.72 & 85.85 & 85.31 \\
\hline
\end{tabular}

Keterangan : *Diolah dari data primer BPS Kabupaten Wonogiri 2014-2018

Pengamatan terhadap periode pembungaan dan pembuahan selama 2014 2018 seperti terlihat pada Gambar 2 dan 3. Dari Gambar 2 diketahui bahwa pembungaan nyamplung TBP Wonogiri terjadi sepanjang tahun meskipun berfluktuasi setiap bulannya. Persen individu yang berbunga setiap bulannya bervariasi selama pengamatan. Pembungaan cenderung mengalami peningkatan pada Januari - Desember 2014 dengan individu berbunga berkisar 0,22\% (Maret) - 23,44\% (Desember). Pada tahun 2015, nyamplung mempunyai dua puncak musim pembungaan, yaitu pada Maret April (53,76\% - 53,98\%) dan Juli - Agustus $(42,58 \%-44,52 \%)$. Persen individu berbunga pada puncak pembungaan tahun 2015 meningkat dua kali lipat dibandingkan tahun sebelumnya, dari 23,44\% (Desember 2014) menjadi 42,58\% - 53,98\% (2015). Musim puncak pembungaan nyamplung pada tahun 2016 juga terjadi dua kali, yaitu pada bulan Maret (52,90\%) dan November (55,91\%). Pengamatan pembungaan pada tahun 2017 dan 2018 cenderung menurun dibandingkan pengamatan tahun sebelumnya. Puncak pembungaan terjadi pada bulan Mei 2017 dengan jumlah individu berbunga $41,29 \%$ dan 23,59\% pada Juni 2018. Dengan demikian hingga umur 7 tahun (akhir tahun 2018) pembungaan nyamplung di TBP belum stabil meskipun pembungaannya sudah dimulai sejak umur 1,5 tahun.

Pembungaan nyamplung di TBP Wonogiri terjadi sepanjang tahun (Januari hingga Desember) dengan 1 - 2 puncak pembungaan setiap tahunnya. Kondisi ini 
semakin memperkuat informasi sebelumnya yang menyatakan bahwa nyamplung mampu berbunga sepanjang tahun (Atabani \& César, 2014; Bustomi et al., 2008; Friday \& Okano, 2006; Prabakaran \& Britto, 2012). Periode puncak pembungaan nyamplung di TBP Wonogiri lebih banyak terjadi pada bulan Maret hingga Agustus (Tabel 2) (akhir musim hujan hingga musim kemarau). Serbuk sari nyamplung bersifat relatif basah dengan bentuk dan warna bunga yang menarik dan harum sehingga menarik perhatian agen penyerbuk. Agen penyerbuk pada nyamplung adalah serangga yang didominasi oleh lebah, kumbang dan semut, dan merupakan agen pembawa serbuk sari yang cukup efektif (Nurtjahjaningsih et al., 2012, 2019). Tanaman penghasil biofuel yang lain misalnya jarak pagar (Jatropha curcas) ekotipe Nusa Tenggara Barat juga memiliki pembungaan sepanjang tahun dengan 2 kali puncak pembungaan pada awal (November - Februari) dan akhir (April - Mei) musim penghujan (Santoso et al., 2011). Sedangkan malapari/kranji (Pongamia pinnata) di Batukaras (Jawa Barat), TN Alas Purwo (Jawa Timur) dan Carita (Banten) hanya memiliki satu periode pembungaan setiap tahunnya pada bulan Maret - April (Batukaras dan Carita) dan Juli - Agustus (Alas Purwo) (Djam \& Gede, 2014; Syamsuwida et al., 2015).

Persentase individu berbunga pada puncak pembungaan nyamplung di TBP Wonogiri berkisar 23,44\% hingga 53,97\%. Pinyopusarerk dan Harwood (2003) merekomendasikan untuk mengoleksi benih hasil dari setidaknya 50\% individu berbunga di suatu sumber benih agar terhindar dari inbreeding. Konsekuensi apabila benih diperoleh pada saat tidak musim berbunga melimpah kemungkinan memiliki keragaman genetik rendah, tingkat inbreeding dan kekerabatan genetik tinggi (Nurtjahjaningsih et al., 2019).

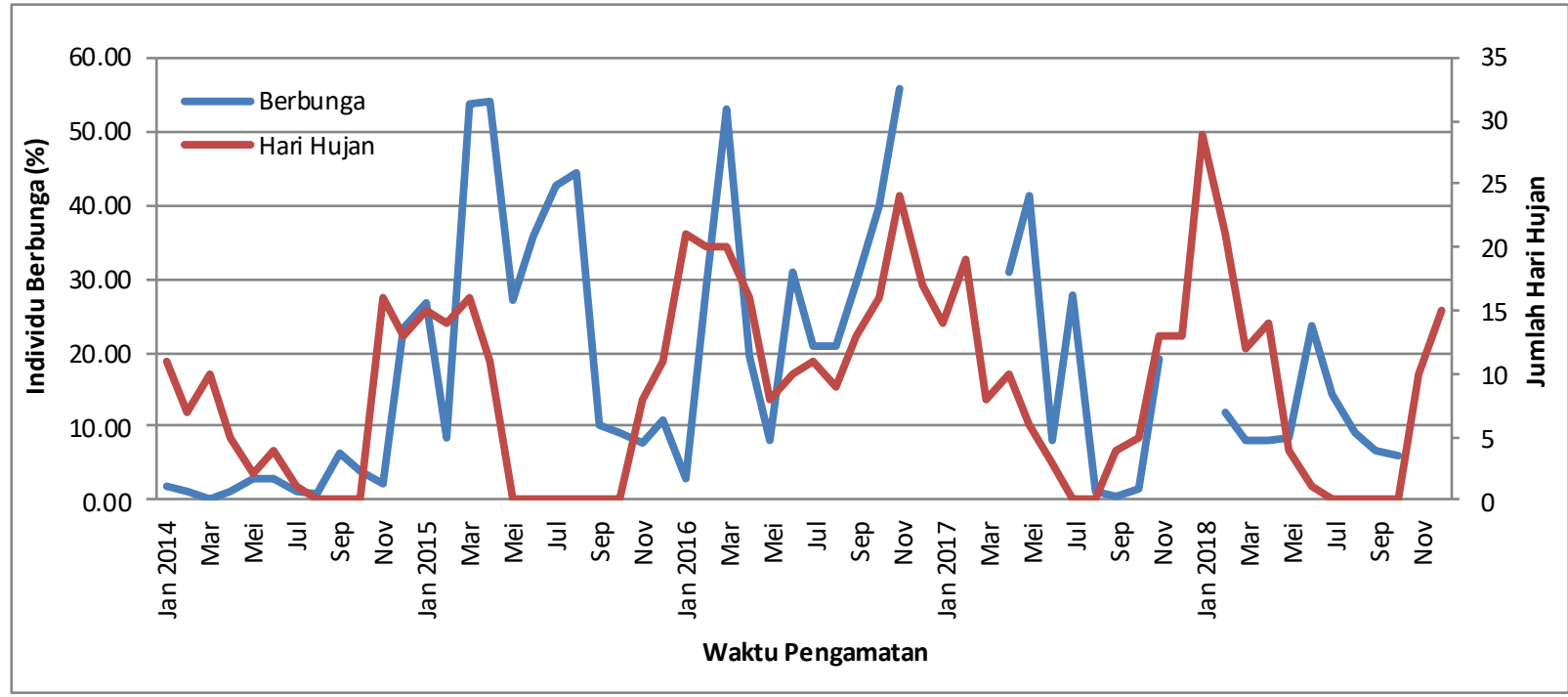

Gambar 2. Persentase individu berbunga

Pada gambar 2 terlihat bahwa puncak pembungaan dengan persentase individu berbunga $>50 \%$ terjadi pada 4 puncak pembungaan, yaitu Maret - April 2015, Maret dan November 2016. Dengan demikian, meskipun belum stabil, nyamplung di TBP dapat mencapai $>50 \%$ individu berbunga pada umur 4 - 5 tahun. Sebagai pembanding, beberapa jenis Eukaliptus di Asia dan Australia mencapai 50\% individu berbunga pada umur 4 7 tahun (Pinyopusarerk \& Harwood, 2003). Kayu putih umur 14 tahun pada kebun benih di Paliyan Gunung Kidul mempunyai kontribusi individu berbunga mencapai $75 \%$ (Kartikawati, 2015). Persentase individu berbunga juga dapat menunjukkan pola pembungaan yang terjadi. 
Nyamplung memiliki pola pembungaan yang cenderung tidak serempak (Bustomi et al., 2008; Friday \& Okano, 2006; Nurtjahjaningsih et al., 2012), sedangkan kayu putih di Kebun Benih Paliyan cenderung serempak (Kartikawati, 2015).

Tren pembungaan yang cenderung menurun pada 2017 dan 2018 diindikasikan sebagai efek dari kerapatan tajuk pada TBP. Jarak tanam nyamplung di TBP Wonogiri adalah $5 \times 5 \mathrm{~m}$. Rerata diameter tajuk pada akhir 2016 sudah mencapai 5,32 - 5,75m (Leksono et al., 2016), sehingga pada 2017 dan 2018 tajuk sudah semakin rapat. Penjarangan pertama sebesar 25\% telah dilakukan pada akhir 2017, namun dari pengamatan di lapangan belum mampu mengurangi kerapatan tajuk secara signifikan. Tajuk yang rapat akan membatasi intensitas cahaya yang diterima oleh tanaman. Kecukupan cahaya matahari berhubungan dengan tingkat fotosintesis sebagai sumber energi bagi proses pembungaan. Kerapatan tajuk yang lebih rendah memiliki jumlah pembungaan dan pembuahan yang lebih tinggi dibandingkan pada kondisi tajuk yang lebih rapat (Nurtjahjaningsih et al., 2012; Syamsuwida et al., 2015).

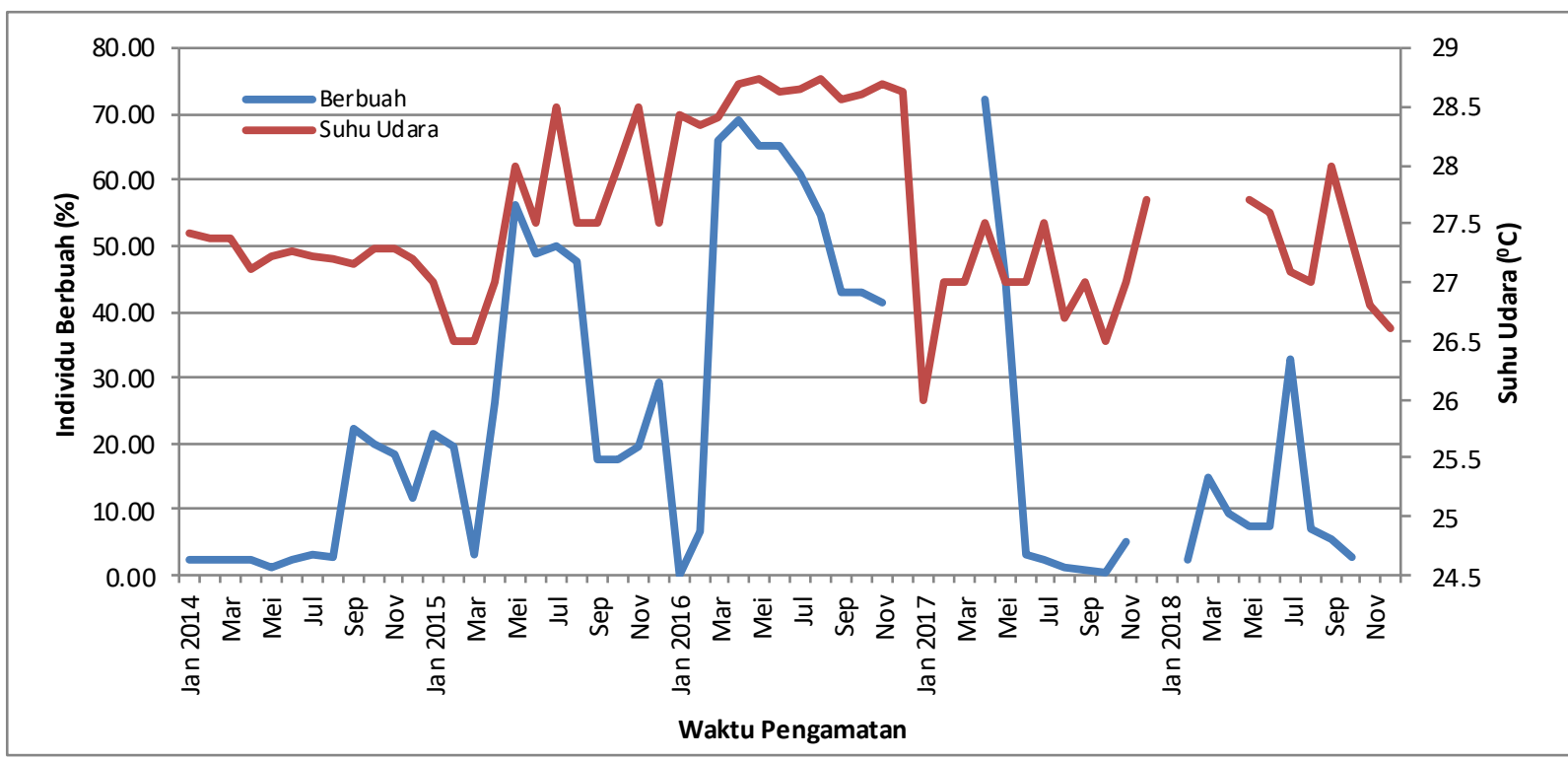

Gambar 3. Persentase individu berbuah

Gambar 3 menunjukkan bahwa nyamplung pada TBP Wonogiri memiliki pembuahan yang cenderung meningkat pada periode Januari 2014 hingga April 2017, yang terlihat dari meningkatnya persentase individu berbuah pada puncak pembuahan pada tahun 2014 - 2017. Puncak pembuahan tahun 2014 terjadi pada bulan September $(22,15 \%)$. Pada tahun 2015 dan 2016 puncak pembuahan terjadi dua kali dalam setahun. Puncak pembuahan pada tahun 2015 pada bulan Mei - Agustus $(47,53 \%$ - 56,34\%) dan Desember $(29,25 \%)$, sedangkan puncak pembuahan pada tahun 2016 terjadi pada bulan Maret - Agustus (54,84\% $69,03 \%)$ dan Oktober (43,01\%). Pada tahun
2017, puncak pembuahan nyamplung terjadi pada bulan April - Mei dengan individu berbuah sebanyak 44,95\% - 72,26\%. Pada tahun 2018 terjadi 2 puncak pembuahan meskipun dengan persentase yang kecil, yaitu 14,62\% (Maret) dan $32,82 \%$ (Juli). Pada beberapa waktu pengamatan, jumlah individu berbuah di TBP lebih banyak dibandingkan jumlah individu berbunga. Kondisi yang serupa juga terjadi pada pembungaan pembuahan di Taman Nasional Kibale (Uganda) dan diduga disebabkan oleh durasi pembungaan yang pendek, sementara pohon bisa berbuah selama beberapa bulan (Chapman et al., 1999). 
Tabel 2. Periode puncak pembungaan pembuahan TBP nyamplung Wonogiri

\begin{tabular}{|c|c|c|c|c|c|c|c|c|c|c|c|c|}
\hline \multirow{2}{*}{ Pengamatan } & \multicolumn{12}{|c|}{ Puncak pembungaan pembuahan } \\
\hline & Jan & Feb & Mar & Apr & Mei & Jun & Jul & Agu & Sep & Okt & Nov & Des \\
\hline \multicolumn{13}{|l|}{2014} \\
\hline \multicolumn{13}{|l|}{2015} \\
\hline \multicolumn{13}{|l|}{2016} \\
\hline \multicolumn{13}{|l|}{2017} \\
\hline \multicolumn{13}{|l|}{2018} \\
\hline \multirow[t]{3}{*}{ Keterangan : } & \multirow{2}{*}{\multicolumn{12}{|c|}{$\begin{array}{l}\text { Pembungaan } \\
\text { Pembuahan }\end{array}$}} \\
\hline & & & & & & & & & & & & \\
\hline & \multicolumn{12}{|c|}{ Pembungaan dan Pembuahan } \\
\hline
\end{tabular}

Seperti halnya pada pembungaan, periode puncak pembuahan nyamplung juga lebih banyak terjadi pada bulan Maret - Agustus (Tabel 2), dimana periode tersebut merupakan akhir musim hujan hingga mendekati akhir musim kering. Sebagai pembanding, nyamplung dari 6 populasi di Jawa memiliki musim buah raya sbb : April - Agustus (Alas Purwo), Oktober - November (Gunungkidul), Purworejo (Agustus - September), Juni - Agustus (Cilacap), Agustus - September (Ciamis) dan Juni - Agustus (Banten) (Leksono et al., 2010).
Puncak pembungaan dari 104 spesies pohon di hutan tropis Taman Nasional Kibale (Uganda) juga bervariasi, namun lebih sering terjadi pada akhir musim hujan dan awal musim kemarau (Chapman et al., 1999). Pada 38 spesies pohon di Taman Nasional Tai (Afrika Barat) puncak pembuahan terjadi pada akhir musim penghujan dan berlanjut hingga musim kering yang pendek (Mei hingga Agustus) (Anderson et al., 2005). Sebaliknya pada hutan tropis kering di Timur Laut Taiwan, banyak tanaman bereproduksi pada peralihan musim kering ke musim penghujan (Chang Yang et al., 2013).

Tabel 3. Korelasi pembungaan pembuahan dan iklim pada TBP Wonogiri

\begin{tabular}{lcccccc}
\hline & Berbunga & Berbuah & Hari hujan & CH & Suhu udara & Kelembaban \\
\hline Berbunga & 1 & & & & & \\
Berbuah & 0.57 & 1 & & & & \\
Hari hujan & 0.32 & 0.16 & 1 & & & \\
CH & 0.21 & 0.04 & 0.84 & 1 & & \\
Suhu udara & 0.28 & 0.61 & 0.22 & 0.02 & 1 & \\
Kelembaban & -0.04 & -0.19 & 0.25 & 0.32 & -0.12 & 1 \\
\hline
\end{tabular}

Variasi pola pembungaan dan pembuahan tanaman di daerah tropis sangat sensitif terhadap fluktuasi faktor lingkungan seperti suhu dan intensitas curah hujan. Jika kondisi lingkungan tidak memungkinkan untuk berbunga dan berbuah, tanaman akan menunda periode pembungaan pembuahan atau mengurangi intensitasnya hingga kondisi lingkungan memungkinkan. Faktor lingkunganakan mempengaruhi periode dan produktivitas bunga dan buah melalui pergeseran musim pembungaan dan pembuahan (Anderson et al., 2005; Winarni et al., 2016). Korelasi antara pembungaan pembuahan dengan iklim pada TBP Wonogiri seperti terlihat pada Tabel 3. Hari hujan menjadi faktor yang paling mempengaruhi pembungaan, sedangkan pembuahan dipengaruhi kuat oleh suhu udara dengan nilai korelasi berturut-turut sebesar 0,32 dan 0,61. Pembungaan dan pembuahan berkorelasi positif dengan hari hujan, curah hujan dan 
suhu udara. Gambaran korelasi pembungaan dengan hari hujan serta pembuahan dengan suhu udara juga seperti terlihat pada Gambar 2 dan 3. Iklim hangat dan tingginya curah hujan dapat merangsang pertumbuhan tunas dan pembungaan pada 21 klon kakao harapan (Anita-sari \& Susilo, 2013).

Informasi periode pembungaan dan pembuahan pada nyamplung di TBP Wonogiri akan berimplikasi terhadap pengelolaan tegakan berikutnya. TBP memiliki pola pembungaan yang cenderung tidak serempak dan sistem perkawinan yang cenderung outcrossing (Nurtjahjaningsih et al., 2012, 2019). Kerapatan tajuk diduga kuat menjadi penyebab utama menurunnya pembungaan dan pembuahan pada pengamatan 2 tahun terakhir (2017 dan 2018), hal ini berpengaruh terhadap produksi buah di TBP. Rerata diameter tajuk pada 2 plot ukur permanen (PUP) secara berturut-turut berkisar 4,30 - 5,16 m (2015) dan 5,32 - 5,75 m (2016). Dengan demikian sejak 2016 diameter tajuk sudah saling bersentuhan dan rapat karena melampaui jarak tanam awal sebesar $5 \times 5 \mathrm{~m}$ (Leksono et al., 2016, 2017, 2018). Upaya yang dapat dilakukan untuk memperbaiki kondisi tersebut antara lain dengan melakukan penjarangan kedua terutama terhadap individu - individu yang tidak/kurang produktif. Selain itu juga dapat dilakukan pemangkasan pucuk (top pruning) untuk mengurangi kerapatan tajuk sekaligus memicu munculnya tunas baru serta memudahkan teknis pengamatan dan pengunduhan buah. Serangga polinator juga menyukai kondisi dengan sinar matahari yang cukup dan tajuk yang cenderung terbuka sehingga bunga lebih mudah terlihat oleh mata facet serangga (Nurtjahjaningsih et al., 2012). Dengan demikian diharapkan dapat meningkatkan efektivitas penyerbukan dan terjadinya pembuahan. Pemberian pupuk dan hormon tertentu untuk merangsang pembungaan pembuahan juga dapat dilakukan di TBP. Pengamatan lebih lanjut dan mendetail terhadap pembungaan pembuahan nyamplung di TBP masih diperlukan, termasuk informasi produksi buah.

\section{KESIMPULAN}

Periode pembungaan dan pembuahan nyamplung pada tahun 2014 - 2018 di TBP Wonogiri terjadi sepanjang tahun dengan karakter pembungaan dan pembuahan yang bervariasi. Puncak pembungaan dan pembuahan lebih banyak terjadi di bulan Maret - Agustus (akhir musim penghujan hingga pertengahan musim kemarau). Secara umum pembungaan dan pembuahan meningkat pada tahun 2014 - 2016, kemudian menurun pada tahun 2017 - 2018. Hal ini diduga dipengaruhi oleh semakin tingginya kerapatan tajuk. Faktor lingkungan yang paling mempengaruhi pembungaan adalah hari hujan, sedangkan pembuahan dipengaruhi kuat oleh suhu.

\section{UCAPAN TERIMA KASIH}

Penelitian ini dibiayai oleh DIPA Kementerian Lingkungan Hidup dan Kehutanan. Peneliti mengucapkan terima kasih kepada Arif Priyanto, Hendra Firdaus dan Didik Indriatmoko yang telah membantu pengumpulan data di lapangan selama 5 tahun pengamatan.

\section{DAFTAR PUSTAKA}

Anderson, D. P. ., Nordhelm, E. . V. ., Moermond, T., Boesch, Z. B. ., Bi, G., \& Christophe. (2005). Factors Influencing Tree Phenology in Taï National Park. Journal Biotropica, $37(4)$, 631-640. https://www.jstor.org/stable/30043230

Anita-sari, I., \& Susilo, A. W. (2013). Stabilitas Karakter Pembungaan , Pertunasan , dan Potensi Jumlah Buah pada 21 Klon Kakao Harapan Koleksi Puslitkoka. Pelita Perkebunan, 29(2), 82-92. https://adoc.pub/stabilitas-karakterpembungaan-pertunasan-dan-potensijumlah.html

Atabani, A. E., \& César, S. (2014). Calophyllum inophyllum L. A prospective non-edible biodiesel feedstock. Study of biodiesel production, properties, fatty acid 
composition, blending and engine performance. Journal Renewable and Sustainable Energy Reviews, 37, 644-655. https://doi.org/https://doi.org/10.1016/j.rser.2 014.05 .037

Bala, M., Nag, T. N., Kumar, S., Vyas, M., \& Kumar, A. (2011). Proximate Composition and Fatty Acid Profile of Pongamia pinnata, a Potential Biodiesel Crop. Journal American Oil Chemists's Society, 88, 559-562. https://doi.org/10.1007/s11746-010-1699-2

Baskorowati, L. (2013). Pengaruh faktor lingkungan terhadap intensitas pembungaan Melaleuca alternifolia. Jurnal Pemuliaan Tanaman Hutan, 7(1), 15-28.

\section{BBPPBPTH. (2013). KHDTK Wonogiri. BBPPBPTH Jogja.}

Bustomi, S., Rostiwati, T., Sudrajat, R., Leksono, B., Kosasih, A., Anggraeni, L., Syamsuwida, D., Lisnawati, Y., \& Djaenudin, D. (2008). Nyamplung (Calophyllum inophyllum L) sumber energi biofuel yang potensial. Badan Penelitian dan Pengembangan Kehutanan.

Chang Yang, C., Lu, C., Sun, I., \& Hsieh, C. (2013). Flowering and Fruiting Patterns in a Subtropical Rain Forest, Taiwan. Journal Biotropica, 45(2), 165-174.

Chapman, C., Wrangham, R., Chapman, L., Kennard, D., \& Zanne, A. . (1999). Fruit and Flower Phenology at Two Sites in Kibale National Park Uganda. Journal of Tropical Ecology, 15(2), 189-211.

Darwo, \& Bogidarmanti, R. (2016). Prospek Budidaya Bintangur (Calophyllum soulatri) untuk Dikembangkan di Lahan Gambut. Prosiding Seminar Nasional Masyarakat Biodiversitas Indonesia, 2(2), 267-270. https://doi.org/10.13057/psnmbi/m020225

Djam, D. F., \& Gede, P. P. (2014). Fase Pembungaan dan Pembuahan Tanaman Kranji (Pongamia pinnata (L) Pierre) di Carita Banten. Jurnal Perbenihan Tanaman Hutan, 2(2), 59-65.

Friday, J. B., \& Okano, D. (2006). Calophyllum inophyllum (kamani), ver.2.1. Species Profiles for Pasivic Island Agroforestry. Permanent Agriculture Resources (PAR), April, $\quad 1-17 . \quad$ https://www.docdeveloppement-

durable.org/file/Culture/Arbres-Bois-deRapport-

Reforestation/FICHES_ARBRES/calophyllu $\mathrm{m}$ inophyllum/Calophyllum inophyllum (Kamani).pdf

Hamim, Romadlon, Z., \& Dorly. (2019).
Perkembangan morfo-anatomi bunga, buah, dan biji nyamplung (Calophyllum inophyllum L), sebagai tanaman penghasil biodisel. Jurnal Sumberdaya Hayati, 5(1), 110.

Handoko, C., Wahyuni, R., Agustarini, R., \& Anggadhania, L. (2013). Pengaruh variabelvariabel lingkungan terhadap periode pembungaan dan pembuahan nyamplung (Calophyllum inophyllum): Studi kasus di Pulau Lombok dan Nusa Penida. Proceedings of the National NTFP Seminar 'Peranan Hasil Litbang HHBK Dalam Mendukung Pembangunan Kehutanan.'

Herman, M., Syakir, M., Pranowo, D., Saefudin, \& Sumanto. (2013). Kemiri Sunan (Reutealis trisperma (Blanco Ar.Shaw) Tanaman Penghasil Minyak Nabati dan Konservasi Lahan. IAARD Press.

Kartikawati, N. K. (2015). Indeks overlap dan sinkronisasi pembungaan dalam kebun benih kayu putih (Melaleuca cajuputi) di Paliyan Gunungkidul. Jurnal Pemuliaan Tanaman Hutan, 9(2), 103-115.

Leksono, B., Hendrati, R. L., Windyarini, E., \& Hasnah, T. M. (2014). Variation in Biofuel Potential of Twelve Calopyllum Inophyllum Populations in Indonesia. Indonesian Journal of Forestry Research, 1(2), 127-138. https://doi.org/10.20886/ijfr.2014.1.2.127138

Leksono, B., Lisnawati, Y., Rahman, E., \& Putri, K. P. (2010). Potensi tegakan dan karakteristik lahan enam populasi nyamplung (Calophyllum inophyllum) ras Jawa. Prosiding Workshop Sintesa Hasil Penelitian Hutan Tanaman, 397-408.

Leksono, B., Sukartiningsih, Windyarini, E., Adinugraha, H. A., Yustina, A., Kwon, J., \& Baral, H. (2020). Growth Performance of Calophyllum inophyllum at a Bioenergy Trial Plot in Bukit Soeharto Research and Education Forest, East Kalimantan. International Bioenergy and Biomass Conference.

Leksono, B., \& Widyatmoko, A. (2010). Strategi pemuliaan nyamplung (Calophyllum inophyllum) untuk Bahan Baku Biofuel. National Seminar Sains and Teknologi III: Peran Strategis Sains Dan Teknologi Dalam Mencapai Kemandirian Bangsa, 125-137.

Leksono, B., Windyarini, E., \& Hasnah, T. M. (2013). Laporan Hasil Penelitian: Pemuliaan Jenis Nyamplung untuk Biofuel.

Leksono, B., Windyarini, E., \& Hasnah, T. M. 
(2015). Laporan Hasil Penelitian: Pemuliaan Jenis Nyamplung untuk Biofuel.

Leksono, B., Windyarini, E., \& Hasnah, T. M. (2016). Laporan hasil penelitian: Pemuliaan Jenis Nyamplung untuk Biofuel.

Leksono, B., Windyarini, E., \& Hasnah, T. M. (2017). LAPORAN HASIL PENELITIAN TAHUN 2017: Pemuliaan Tanaman Hutan Penghasil Energi: Jenis Nyamplung dan Malapari (Issue Rppi 5).

Leksono, B., Windyarini, E., \& Hasnah, T. M. (2018). Laporan Hasil Penelitian: Pemuliaan Tanaman Hutan Penghasil Energi: Jenis Nyamplung untuk Biofuel.

Nurtjahjaningsih, I. L. G., Sulistyawati, P., \& Rimbawanto, A. (2019). Struktur genetik pohon induk Calophyllum inophyllum di tegakan benih provenan berdasarkan penanda Simple Sequence Repeats. Jurmal Pemuliaan Tanaman Hutan, 13(1), 45-51.

Nurtjahjaningsih, I. L. G., Sulistyawati, P., Widyatmoko, A., \& Rimbawanto, A. (2012). Karakteristik pembungaan dan sistem perkawinan nyamplung (Calophyllum inophyllum) pada hutan tanaman di Watusipat, Gunungkidul. Jurnal Pemuliaan Tanaman Hutan, 6(2), 65-80.

Pinyopusarerk, K., \& Harwood, C. (2003). Flowering and Seed Production in Tropical Eucalyptus Seed Orchards. ACIAR Proceeding No 111 Australian Centre for International Agricultural Research Canberra, 111, 247-248.
Prabakaran, K., \& Britto, S. J. (2012). Biology, Agroforestry and Medicinal Value of Calophyllum inophyllum L. (Clussiacea): A Review. International Journal of Natural Products Research, 1(2), 24-33.

Santoso, B. B., Susanto, S., \& Purwoko, S. (2011). Pembungaan Jarak Pagar (Jatropha curcas L.) beberapa Ekotipe Nusa Tenggara Barat T. Jurnal Agronomi Indonesia (Indonesian Journal of Agronomy), 39(3), 210-216.

Syamsuwida, D., Purwaka, K., Kurniaty, R., \& Aminah, A. (2015). Seeds and Seedlings Production of Bioenergy Tree Species Malapari (Pongamia pinnata (L.) Pierre). Prosiding Indo-EBTKE Conex 2014, 65, 6775.

https://doi.org/10.1016/j.egypro.2015.01.033

Winarni, N. L., Kurniasari, D. R., Hartiningtias, D., \& Nusalawo, M. (2016). Phenology, Climate, and Adaptation: How Does Dipterocarps Respond to Climate? Indonesian Journal of Forestry Research, 3(2), 129-141.

Windyarini, E., \& Hasnah, T. M. (2014). Pertumbuhan benih unggul nyamplung (Calophyllum inophyllum) pada tingkat kesuburan tanah yang berbeda di Wonogiri. Proceedings from the National Seminar Benih Unggul Untuk Hutan Tanaman, Restorasi Ekosistem Dan Antisipasi Perubahan Iklim SEAMEO BIOTROP, 233245. 